\title{
Piracy as Labour Struggle
}

\author{
Gavin Mueller
}

\section{George Mason University, Fairfax, VA, gavinmueller@gmail.com}

\begin{abstract}
This paper examines the organization of digital piracy in the context of reshaping labour under neoliberalism. It discusses the practices by which enclosures of intellectual property are resisted by drawing from literature on the labour process, and examining the historical emergence of piratical practice on electronic bulletin board systems. These pirates sought, above all, to preserve autonomous, self-managed working conditions in the face of tendencies to commodify, enclose, and deskill.
\end{abstract}

Keywords: Intellectual property, piracy, neoliberalism, cultural studies, digital media, social organization

Piracy has long been the specter haunting capitalism in the digital era: from the early days of personal computing, piracy-the violation of established laws of intellectual property, primarily centered around the unauthorized distribution of digitized commodities such as software, music, film, and books - was raised as the enemy of the commercial future of consumerlevel computing. In content industry discourse, piracy is treated as an existential threat to the economy, likened in industry education campaigns to whatever danger reigns supreme at a given point in time: theft, murder, terrorism, and most recently, a cause of unemployment (Creative America).

While the ultimate economic effects of media piracy are difficult to establish, repressive measures taken by the content industry have provoked a political battle. The fight to extend control of intellectual property in the digital realm has been likened to a "second enclosure movement" (Boyle 2003), a reference to the enclosure of common lands in the 18th Century that turned dispossessed peasants into a labouring force for emerging industrial capitalism (Marx 1990). Thompson (1966) and Rediker and Linebaugh (2005) document the resistance to such enclosures and the new capitalist relations they imposed, by people who were subsequently dubbed pirates and outlaws. If, as Boyle and Benkler (2006) suggest, the Internet represents a new kind of commons, digital piracy emerges as the resistance to its enclosure: a way to maintain a mode of existence in the face of the restructuring of social and economic relations.

The transformation of the common land into fenced-off private property had cascading effects. Without access to common resources, peasants and artisans were unable to maintain their previous way of life, and were pushed from subsistence activity into reliance on wage labour and the market to survive (Wood 2002). Once they took up wage labour for capitalists in factories, workers were further subject to dehumanizing and mechanized work routines. Separation from the commons was a precondition for restructuring the labour process away from feudal craft techniques and toward increasingly deskilled wage labour in factories. $\mathrm{Re}-$ sistance to the onset of capitalist social relations, then, opposed the enclosures themselves, as well as the new labour processes that were the lived experience of the loss of autonomy. Thompson chronicles fence breakers, such as the Levellers and the Diggers, but machine breakers, such as the Luddites, who attempted to defend craft labour practices in the face of mechanization. In Rediker's (2004) account of Atlantic piracy of the same time period, piracy's appeal to sailors is one of democratic working conditions and profit-sharing, as opposed to the exploitative and hierarchical organization of merchant and military vessels. Struggles over labour processes and the organization of work are important elements in the resistance to enclosure, and thus a key to understanding the politics of piracy.

This paper will argue that digital piracy takes the form of a struggle over digital labour processes, processes, which tend to blur the distinction between production and consump- 
tion. I will examine the practices of pirates as they emerged from the electronic Bulletin Board Systems (BBS) underground and crystallized in the era of the Web. While these digital pirates expressed occasional concern about the institution of private property, they were really animated by the ways copyright enforcement threatened their preferred ways of developing their skills, exploring and communicating in digital environments, and consuming products. In short, their struggle was over autonomy over their productive processes, and enshrining the privileges therein.

\section{Neoliberal Restructuring and the Social Factory}

The new enclosures of the contemporary era, taking the form of intellectual property, must be understood within a larger process of capitalist restructuring. This restructuring, periodized as "late capitalism" (Mandel, 1978), "post-Fordism" (Aglietta 1979), or more recently, "neoliberalism" (Harvey 2005), saw transformations in private property forms as well as labour processes.

This restructuring was touched off by a crisis in the previous mode of accumulation. Capitalism had achieved several decades of relative stability following World War II. The Keynesian compromise between capital and labour furnished a "social wage" for workers in the form of health care benefits, pensions, public education and the like: the welfare state, responsible for reproducing a working class suitable to the labour needs of capital. This social wage was a means to stabilize Keynesian bargaining strategies, by tying steady increases in productivity (in Marxian terms, relative surplus value extraction) to wage increases. Under this arrangement, consumption of commodities and the reproduction of the working class could become as regulated as production, thereby avoiding crises and labour struggles that had characterized industrial capitalism prior to World War II.

However, capitalism was thrown back into global crisis by the end of the 1960s, beset by difficulties everywhere. Some of these difficulties had to do with larger structural dynamics in the capitalist world system. Europe and Japan had finally rebuilt their industrial capacity, which meant that global capitalism suffered from an overinvestment in fixed capital and increasing global competition (Brenner 2006). The decolonization of the Global South, in turn, threatened to deprive the advanced capitalist world its reliable markets and cheap natural resources.

Other challenges to capital were internal. New vectors of class struggle appeared in the form of "new social movements," from the mobilizations of unwaged housewives, to students organizing against the war, to the anti-nuclear movement (Midnight Notes Collective 1979), which often targeted social institutions such as the family, the university, and the military. The relevance of these struggles was not always understood by socialist and communist movement theory, which tended to prioritize the struggles of a specific type of worker: the one located at the immediate point of production (often in the figure of the "blue collar" factory worker).

Such a perspective derived from an interpretation of Marx's (1990) labour theory of value. According to this theory, capitalism functions by extracting surplus value from workers. Workers generate value in productive processes, for which they receive a wage. However, this wage will never cover all the value created, as the capitalist assumes a portion of value produced as profit. Marx formulates this not as underpayment, but as labour beyond what is necessary to reproduce the worker. This surplus labour is unpaid work for the benefit of the capitalist, not the worker. Absolute surplus value is produced by extending the hours of work; relative surplus value comes from intensifying the labour process through technology, extracting more surplus value during time labouring. Marxists have historically focused on the struggles which break out in this process: workplace struggles over wages, the length of the working day, and working conditions.

However, capitalism requires more than just surplus value to reproduce its social relations. For example, it relies upon "unproductive" and unwaged labour outside of formal employment. Dalla Costa and James (1975) argue, for instance, that unpaid housework is an essential component in reproducing the workforce on a daily basis. Autonomist Marxism has 
developed an analysis of the articulation of processes of production and social reproduction beyond the workplace into a concept: the social factory (Gill and Pratt 2008). According to this analysis, capitalism relies not merely on productive labour at the point of production, but also the myriad practices which reproduce capitalism, and which were subject to increasing intervention from the state and from business. Nick Dyer-Witheford $(1999,134)$ has summarized the autonomist position: "Tronti, writing in the 1960s, argued that capital's growing resort to state intervention and technocratic control had created a situation where the entire society now functions as a moment of production." Capitalism and the state had extended control beyond the workplace to the routines, capacities, and organization of the population outside it: precisely the points of struggle for the new social movements.

Cleaver (2000) has explained the social factory thesis as "productive consumption":

\begin{abstract}
Capital tries to shape all "leisure," or free-time, activities_language, literature, art, music, television, news media, movies, theatres, museums, sports-in its own interests. Thus, rather than viewing unwaged "non-labour time" automatically as free time or as time completely antithetical to capital, we are forced to recognize that capital has tried to integrate this time, too, within its process of accumulation so that recreation is only the recreation of labour-power. Put another way, capital has tried to convert "individual consumption" into "productive consumption" by creating the social factory (123).
\end{abstract}

Cleaver's critique of leisure echoes other theorists such as Adorno (2001) and Debord (1995), who also recognized "free time" as an extension of capitalist social relations. Marx $(1911,278)$ too implies this, describing production and consumption as two essential moments of the capitalist process: "Production is thus at the same time consumption, and consumption is at the same time production. [...] consumption in its turn furthers production by providing for its products the individual for whom they are products." As Stuart Hall (2003, 123) interprets Marx, "Production, then, forms objectively the modes of appropriation of the consumer, just as consumption reproduces production as a subjectively experienced impulse, drive or motive." In other words, consumptive practices have a hold over production. It is, therefore, a site of struggle.

The social factory thesis allows diverse struggles, even those not involved at the direct process of production, to be understood as part of the larger struggle between the working classes and capital. As Dyer-Witheford $(1999,148)$ puts it, "Understood in the light of autonomist analysis, these diverse eruptions, while distinct, are not disconnected. Rather, they appear as a broad revolt by different sectors of labour against their allotted place in the social factory." Part of this revolt will center on the distribution and consumption of commodities.

\title{
2. The Fragment on Machines, Taylorism and the Control Society
}

Capitalism was forced to restructure to outflank the rebellions erupting within factories, both industrial and social. Technology played a vital role. Moody $(1997,67)$ notes that "technology enables the greater separation of production locations, making cross-border production chains viable as never before," allowing capital to seek cheaper, less organized labour markets around the globe. Smith (2000) details how the use of new computer technologies in the production process served to introduce efficiencies and eliminate waste, allowing firms to shed workers and render employment leaner and more flexible. Vast investments in information technology (IT) allowed corporations to disaggregate the large centralized facilities of the Fordist "mass worker" into smaller, subcontracted units, while exploiting the wage differentials of global uneven development, creating a new global division of labour. IT thus serves a communication and coordination function, but also impinges on production itself. The global IT network created new forms of work, often precarious, surrounding the digitization of information and its subsequent manipulation: data entry, system administration, and software programming.

Numerous theorists have attempted to conceptualize new forms of production emerging from the implementation of IT. Labour has been described as "immaterial" (Lazzarato 1996), 
"biopolitical" (Hardt and Negri 2000) or "cognitive" (Boutang 2012), where the intellectual and creative faculties of knowledge workers become the grounds for exploitation. Furthermore, technology has automated labour processes so that workers play a far more insignificant role in the production of physical commodities, thus altering the composition of the global proletariat. These theories point to a portion of the Grundrisse, the so-called "Fragment on Machines," as a place where Marx anticipated a productive system where machines, rather than human beings, exercise control. Marx $(1993,692,693)$ describes "an automatic system of machinery [...] a moving power that moves itself; this automaton consisting of numerous mechanical and intellectual organs, so that the workers themselves are cast merely as its conscious linkages." Where the worker was once an appendage of a machine in a factory, now the worker serves as a node in a network of productive forces. In such a state, the worker has no need of skills: "it is the machine which possesses skill and strength in place of the worker, is itself the virtuoso, with a soul of its own in the mechanical laws acting through it" (693).

This short passage has been extremely influential to autonomist Marxist theorizations of the transformation of labour under capitalism in the post-Fordist period, along with transformations in class struggle. Instead of physical skills of the mass worker, it is now the cognitive abilities of the worker that become important. Language, the manipulation of symbols, creativity, and flexibility are the abilities of the worker mobilized in production. These theorists point to Marx's description of the "general intellect," by which "general social knowledge has become a direct force of production" (706). The development of information technology, and the accompanying spread of education, have led to a more diffuse and autonomous working class appropriate for the computer age. As Negri $(1996,215)$ describes the new post-Fordist worker is

[...] increasingly directly engaged in labour that is computer related, communicative and, in broad terms, educational or formative [...] imbued and constituted by the continuous interplay between technoscientific activity and the hard work of producing of commodities, by the entrepreneuriality of the networks within which this interaction is organized, by the increasingly close combination of the recomposition of labour time and life time.

Immaterial labour is important to post-autonomist theorists because, according to Hardt and Negri $(2005$ 109) it "has become hegemonic in qualitative terms and has imposed a tendency on other forms of labour and society itself." While still undertaken by a minority of the global workforce, "today labour and society have to informationalize, become intelligent, become communicative, become affective" (ibid).

Boutang (2012) argues that because the era of cognitive capitalism relies upon the valorization of innovation, these new forms of labour simply cannot be rationalized. Innovation -the production of new concepts, ideas, and business models-cannot, by its very nature, be rationalized. Cognitive workers must retain autonomy in order to produce effectively. A similar point is made by Pfeiffer (2014) on the development of labouring capacity in high technology environments. "In order to be productive, cognitive capitalism is condemned to live with new and unprecedented degrees of freedom" (41). The irony is deliberate: the cognitariat are condemned to freedom to innovate, although because this is self-valorization, it is not always recognized as labour, and thus not remunerated by a wage. Yet it is just this selfvalorizing and self-organizing character of immaterial labour that imply, for Hardt and Negri, an egalitarian future: "immaterial labour thus seems to provide the potential for a kind of spontaneous and elementary communism" (294).

Virno $(1996,270)$ pushes this even further via a critique of Marx. Because "Marx completely identified the general intellect with fixed capital," he ignored "the instance when that same general intellect manifests itself on the contrary as living labour" (italics in original). This living labour represents a "mass intellectuality": "the repository of the indivisible knowledges of living subjects and their linguistic cooperation" (ibid), which is a quality of "the whole social labour force in the post-Fordist era" (271). Not only are these cognitive capabilities important to capital, but the creation of a mass intellectuality among the workforce be- 
comes a new source of revolutionary potential, as the cognitive skills acquired by workers cannot be completely subsumed to capitalist production (Virno 2001).

George Caffentzis (2013) has critiqued this account of cognitive capitalism on a number of theoretical grounds, including the abandonment of the labour theory of value and the effacement of the continued importance of low-tech physical labour to reproducing capitalism. Most relevant for this essay, Caffentzis demonstrates that Turing's work on computation reveals that mental labour-the skilled, creative, and innovative work of the immaterial labourers-can also be automated: "if any rule-governed activity is computable, then all repeatable and standardized labour (whether mental or physical) producing commodities is mechanizable" (175). These theoretical points are echoed by a recent spate of popular writing on the coming automation of knowledge worker jobs by algorithms (Steiner 2012; Ford 2015). The very real anxiety expressed by knowledge workers, then, can be the grounds for understanding how class struggle unfolds in the "immaterial" spaces of the Internet. We can expect struggle to consist of a defense of the organization of productive practice against tendencies to enclose, fragment, and deskill.

Caffentzis's critiques track Marx's own intellectual trajectory more closely than critiques emerging from post-autonomist thought and the cognitive capitalist school. What appears in the Grundrisse as a highly ambiguous and suggestive general intellect is refined in Capital (specifically chapters 14 and 15) into the extraction of relative surplus value by machines under the real subsumption of the labour process. This trajectory seems to undermine the autonomist critique of the general intellect -- Marx refined his concepts to highlight, not the potential for mass intellectuality, but rather the way in which the worker becomes an appendage of the machine. What Virno sees as mass intellectuality, Marx describes as technologically deskilled labour that is increasingly socialized using advanced technology.

Harry Braverman's Labour and Monopoly Capital (1999) is perhaps the most sustained analysis of this alternative Marxist theory of machines. Braverman sought to update Marx's work on technology and the labour process for a new conjuncture in capitalism, which utilized new technologies of automation, enabled by the rise of powerful computers to coordinate the labour process. He traced this development to the work of one of capital's greatest scientists, Frederick Winslow Taylor.

While Taylor is often credited with devising "efficiencies" in the work process, Braverman (1999, 78-9) argues that Taylor actually discovered methods to discipline an unruly labour force of skilled workers. Skilled workers possessed an advantage over managers by having a more comprehensive knowledge of the labour process. With this knowledge came greater control over the workplace, enabling workers to perform at their own pace, and giving them leverage in demanding higher wages. In response, Taylor sought the "dissociation of the labour process from the skills of the workers" and the "separation of conception from execution." By fragmenting the labour process into discrete low-skill tasks, management could make "use of this monopoly over knowledge to control each step of the labour process and its mode of execution" (Braverman 1999, 82), forcing workers to perform at the desired pace, and replacing them easily if they resisted. So important was this dynamic of deskilling under capitalism that Braverman (1999, xix, 3) declared that "struggles over job control are the central feature of work under capitalism," leading to revolts over the "mindlessness" and "bureaucratization" of most jobs. Braverman's work predicts that labour struggles will revolve around skill as a means to preserve autonomy over the labour process.

Braverman's focus on the workplace can be extended into the social factory by reference to other work grappling with new forms of power emerging with capitalism's technological restructuring. Deleuze (1990) offers a suggestive reading of this moment. He argues that the era of disciplinary institutions theorized by Foucault (1977), which served to create an industrial labour force at the moment of enclosure, has given way to "societies of control." According to Deleuze $(1990,5,6)$, as disciplinary institutions, responsible for producing discrete subjects such as "soldier" or "worker" break down, people are increasingly subject to a kind of free-floating domination, "postponements" of "continuous variation" enforced by passwords: "codes that mark access to information, or reject it." These are the forms of control over the social factory, where production and reproduction extend beyond "enclosures" into 
"circuits": control relies upon access and credentialing, and capitalist production tends towards the immaterial. Crucially, "societies of control operate with machines of a third type, computers, whose passive danger is jamming and whose active one is piracy and the introduction of viruses." If the social factory is administered via control mechanisms, then struggle will attempt to upend those mechanisms.

As control mechanisms were introduced throughout computer networks, which had become newly important as productive forces and sites of commodity consumption, informal organizations arose to contest them. In their attempts to practice self-management over computer work, the navigation of virtual space, and the increasingly important consumption of digital goods, computer users found means of circumventing the codes and passwords that represented the newest implementation of capitalist control.

\section{Intellectual Property and Early Hacker Struggles}

The origins of the battles over copyright online can be located in the struggle over selfmanagement of work in the face of control mechanisms. As software began to be commodified, companies began to enclose code behind intellectual property protections in order to discipline the way software was consumed. This butted up against established hacker practices of free sharing of code, and the ability to tinker with it and customize it: to self-manage their computer work in a way where production and consumption blended together. To operate autonomously as capitalist imperatives encroached on his work, programmer Richard Stallman devised variations on intellectual property licenses: the so-called "copyleft" of the GNU General Public Licenses. The GPL effectively uses the ironclad law of copyright licensing to require anyone who builds programs from free software to share source code, removing the ability for anyone to monopolize their programs. As Stallman (2009) puts it, "Copyleft uses copyright law, but flips it over to serve the opposite of its usual purpose: instead of a means of privatizing software, it becomes a means of keeping software free."

While much of the work on the Free Software movement has emphasized its liberal rhetoric of civil liberties (see Coleman 2009), it is clear that these politics emerge from a vision of work. Dafermos and Söderberg (2007) have argued that hacker politics such as Stallman's should be understood as a kind of labour struggle against management:

In attempting to escape from alienated existence, the hacker movement has invented an alternative model for organising labour founded on the common ownership of the means of production, on volunteer participation and the principle of self-expression in work. It is this promise that lies at the heart of the politics of the hacker movement (54).

This promise is described by Brown (2014) as adhering specifically to unwaged forms of digital labour. In his account, "Unwaged digital labour is inherently cooperative, collaborative, communal and based predominantly on the non-instrumental sharing of digitized content and data between members of Web 2.0 sites and services." The organization of piratical activity deeply resembles Brown's description of the relation between unwaged digital labour and management:

Free of any kind of management oversight, unencumbered by supervisory directive, absent a structured work environment or duration, removed from the organizational forms so characteristic of hierarchical capitalist command and control, and, undeniably free of the wage relation, unwaged digital labourers devote prodigious amounts of time, energy, intellect, and affect to projects that have the capacity to harness the collective intelligence of a global network of content generators, working at all times of the day, and in every corner of the world.

However, the early piracy under question did not occur in a Web 2.0 environment, where user activity becomes a source of surplus value through the creation of audiences monetized by advertising (See Fuchs 2012 and Manzerolle 2010). In the absence of advertising, and therefore, the lack of an identifiable audience commodity, early software piracy does not 
produce surplus value. In what sense can this activity be described using the tools devoted to understanding labour struggles?

Fuchs (2014) draws a useful distinction between digital work and digital labour:

\begin{abstract}
Digital work is a specific form of work that makes use of the body, mind or machines or a combination of all or some of these elements as an instrument of work in order to organize nature, resources extracted from nature, or culture and human experiences, in such a way that digital media are produced and used. The products of digital work are depending on the type of work: minerals, components, digital media tools or digitally mediated symbolic representations, social relations, artifacts, social systems and communities. Digital work includes all activities that create use-values that are objectified in digital media technologies, contents and products generated by applying digital media (352).
\end{abstract}

Whereas digital labour

is alienated digital work: it is alienated from itself, from the instruments and objects of labour and from the products of labour. Alienation is alienation of the subject from itself (labour-power is put to use for and is controlled by capital), alienation from the object (the objects of labour and the instruments of labour) and the subject-object (the products of labour) (351f).

Early computer culture, at first somewhat independent of direct market imperatives and commodification, embraced digital work in the form of proliferating use-values. However, it struggled mightily against the introduction of private property (in the form of intellectual property) that would alienate hackers and programmers from their products and exert control over their work practices. As Fuchs and Sandoval (2014) put it, "Karl Marx pinpoints this lack of control by the term alienation and understands the unity of these forms of alienation as exploitation of labour." Pirates seek to retain control and halt the subsumption of digital activity towards commodified and alienated practices. In other words, they want to work, not labour.

In order to struggle against this alienation, hackers form informal organizations, existing parallel to the capitalist management of the Internet. Rather than explicitly anti-capitalist, hacker politics emerge from hackers' resistance to the imposition of intellectual property relations, which bar them from access to code. In this way, intellectual property works to divide the moments of production and consumption of software: a deskilled consumer must rely on purchasing software commodities from capitalists, rather than developing their own skills or alternative methods of production and distribution. In the face of this, hackers challenge intellectual property in order to maintain their skill and autonomy, to maintain the craft-like character of their work, in the face of tendencies to deskill and control the use of computers and the navigation of digital space online.

The earliest digital piracy was also concerned with skill and control over labour processes. The hobbyist clubs from which the personal computer industry would emerge shared Stallman's hacker values: the ability to test, deconstruct, learn from, and share software, primarily as a means to build skills in programming and computer networking: a kind of productive consumption. Providing fellow hobbyists with a disk free of charge was a common practice; clubs often taught themselves programming by collaboratively deconstructing software. This did not go unnoticed by the nascent commercial software industry. Bill Gates's (1976) infamous letter excoriating the PC hobbyists who shared his young company's Altair BASIC program set the tone: "most of you steal your software. Hardware must be paid for, but software is something to share. Who cares if the people who worked on it get paid?"

In response to piracy, software companies began to install copy protections, often in the form of segments of code, on their software to prevent users from sharing purchases. As is often the case, these copy protections contained side-effects that adversely affected software purchasers: namely that they could not make back ups. Such protections have raised many objections. Lessig (1999) has warned that these mechanisms take power away from social institutions, such as the judicial system, working for the public good in favor of absolut- 
ist control at the hands of content owners. Gillespie (2009) has sounded a similar note. These copy protections are a perfect example of the control mechanisms described by Deleuze, which regulate access to information, replacing declining social institutions.

When other companies released programs capable of breaking copy protection, such as Locksmith for the Apple II, they were blacklisted from the software magazines, the chief organ for promoting software. This provoked hobbyist Charles Haight to start his own magazine, Hardcore Computing. The first issue begins with an editorial written by Haight's brother Bev $(1981,5)$, excoriating the complicity of magazine publishers with the software industry as censorship and "withholding information in an attempt to mislead their readership."

Haight $(1981,5)$ positions emerging practices of skill development against regressive anti-piracy initiatives. Copyright is an "outdated, obsolete system," and "is one of the obstacles that stand in the way of the technological evolution of information exchange (hereafter called info-x)." The preservation of existing piratical practices is an essential element of developing newly necessary skills, themselves a cornerstone of freedom in the age of "info-x." In this, Haight articulates a moral-technical order akin to the one Kelty (2008) observes in Free Software developers. The use-value of software is reconceived as a pedagogical tool: by tinkering with code, users, productively consuming software, will themselves learn to program. In an act of militant resistance, Hardcore Computing not only ran ads for software such as Locksmith, but also published instructions for how programmers could defeat copy protection by tinkering with source code. These manuals for piracy anticipated the pirate 'zines and tutorials that would soon proliferate over digital networks.

This organized resistance to copyright continued as hacker culture moved to the digital networks of Bulletin Board Systems (BBS), an early way to connect computers via telephone lines. A BBS is not a network in the same sense as today's Internet. BBS systems were more like circuits: users connected their computers by "calling" each other on telephone lines. BBS hosts tailored their boards to particular interests, often connected to exploring the capabilities of computing and telephony. The number of connections was limited by the number of lines, and users were subject to telephone charges. BBS's were more akin to smaller, more exclusive methods of connecting, such as chat rooms, than to the open Web of today.

BBS hosts tailored their boards to particular interests, and competed for users. Skill development through tinkering remained a popular pastime among hobbyists, as did the sharing of software. The ability of a BBS to host files meant that this sharing could be an exclusively digital affair. ${ }^{1}$ Hacker magazines went digital as well, becoming "textfiles" which continued the tradition of anti-corporate discourse and skill-sharing. ${ }^{2}$ This move into networks of organized struggle against the commodification of computing was sometimes referred to as the "computer underground" (Lin 1995). In the computer underground, users could demonstrate mastery and autonomy and challenge the conventions of societal authority.

This computer underground formed around the cachet attached to boasting about disruptive computer practices. These practices included hacking (testing and breaking into systems), phreaking (methods to acquire free telephone time), anarchy (instructions on committing petty crime and vandalism), and viruses (malicious programs), abbreviated at "HPAV". Piracy too became an integral part of the BBS computer underground. Thus, the typical hacker practice of transgressive displays of skill found a new expression in the "cracking" of software protections and the distribution of pirated versions of software and games. The earliest pirates reveled in their rebel identity, much like the Haights, taking pseudonyms that highlighted their illegal activity: the Apple Bandit, the Burglar, Black Bart, Copy/Cat, Rogue Pirate; groups like Midwest Pirates Guild, West Coast Pirate Exchange, Racketeers, Hi-Rez Hijackers.

\footnotetext{
${ }^{1}$ This is only true of the US context. In Europe, due to slower download speeds, pirates would exchange physical discs in the mail. See Reunanen (2014).

${ }^{2}$ An immense digital archive of BBS textfiles (located at textfiles.com) is maintained by Jason Scott, a former BBS hacker and amateur historian.
} 
Initially a way to distribute, test, and learn software, piracy took on a new cast in the BBS underground: it became a competitive quest for status among different bulletin boards (Hardagon 2001), with technical skill as the ultimate status marker. System operators (sysops) of a BBS had control over who could access the board, and therefore any files hosted there. Possessing exclusive files, and having them before anyone else, became a signal that one's bulletin board was part of the elite: those who possess the highest degree of autonomy in digital environments.

Piracy was easily imbricated into the overall values of hacker culture that governed the BBS era. Not only was it a transgressive computer activity. Copy protection on software and video games presented a unique opportunity for hackers to display their skills to their peers. A skilled programmer could tinker with the source code of a program, rendering copy protection useless and making the program available to any user. Breaking copy protection became known as "cracking." Crackers often inserted credit for their deeds inside the software. Décary-Hetu et al. (2012) argue that the entire social organization of warez scene rests on social recognition, though Hardagon $(2001,136)$ amends "the ability to translate this into more favourable access on coveted systems" to the motivations of pirates. To follow Deleuze's logic, access is a highly sought ability, and even a status marker, in societies of control. Unauthorized copies of software became known as "warez," a kind of pirate commodity with its own production and distribution system, and surrounded by its own peculiar set of cultural practices.

\section{The Organization of Early Digital Piracy}

As commercial software and computer networking increased in power and complexity, a division of labour emerged among dedicated pirates. This division was more or less selforganized, determined by the needs of commodity production, the arrangement of the productive forces within computer networks, and according to the established norms and codes of conduct of the computer underground. Technologically determinist perspectives on digital piracy, which posit that piracy is an inevitable side effect of the inadequacies of copyright in the age of digital networks, ignore this organizational element, which might be conceived as the culture of digital piracy. The organization of this culture, termed "The Scene," derives its form from the BBS era and continues into the present day. Many contemporary practices are holdovers from the days of BBS pirates, and The Scene is still the ultimate origin for the majority of pirated releases of content on P2P networks (Howe 2005). Within The Scene, groups of pirates race to be the first to secure and release pirated versions of digital content, a holdover from the days when BBS boards competed for status and members.

Goldman $(2003,396)$ has mapped out The Scene's division of labour:

These operations divide up several discrete tasks among their members, including sourcing new warez, cracking any technological protection devices, testing the cracked warez to make sure they still work, packaging the warez for easy distribution, couriering the warez to propagate the warez to other sites or throughout the Internet, performing systems administration on the computers used by the group, and managing/overseeing the operations.

The first role is that of the supplier, who must acquire the content to be pirated. In the early days of BBS, this simply meant purchasing a program from the store. A BBS could rely on a well-heeled member to do this, but many boards also engaged in credit card fraud to purchase both the hardware required to run a board as well as the programs to distribute on it (Craig 2005). Eventually, pirate organizations established moles inside companies, who could provide them with advanced access to content, giving them a leg up on their pirate competition. Goldman (2003) cites cases in which employees of Intel and Microsoft were prosecuted for cooperating with pirate groups. Witt (2015) profiles a prolific music pirate who worked at an optical disc plant operated by Universal Records. Review copies have been another frequent source, as illustrated in the case of Doom II, which emerged on pirate networks weeks before its official release date (Kline, Dyer-Witheford, and de Peuter 2003), as 
well as the recent case of Ellen Degeneres's screener copy of The Secret Life of Walter Mitty (Spangler 2014). These examples illustrate that pirates are workers in a double sense. Their piratical activity falls in the realm of consumption, which has its own productive character. But pirates are, for the most part, also wage labourers, many in the information technology industry, and some for the very companies their piratical practices undermine. The Scene relies upon an insurgent sector of wage labour, which transforms mundane work into games of status and ability.

The copy protection on software and video games was then subverted by a cracker, a skilled programmer who alters the source code of a program, rendering copy protection useless and allowing copies to proliferate. Crackers do a kind of coding labour by disarming copy protection, but they also go further than this. Sometimes they fix bugs: Wasiak (2012) describes the actual correction of source code: "the removal of all noticed errors and glitches in the original code, since the cracked game was meant to be superior to the original in every possible way" (8). As Reunanen (2014) has put it, "the cracker system can be seen as an offspring and a mirror image of the commercial model." The skill in programming required for cracking have led to crackers becoming a cherished part of the computer underground: they provide a model for how participants can train themselves in programming skill. As Pirate Magazine, one of the many 'zines put together in the BBS underground, describes it, "Cracking is about learning computer programming, and the fun is in increasing skills." It is "one of the best (and most fun) ways to learn about what makes a program work" ("Cracking Tips (Part 1)").

Once cracked, programs are transferred by couriers to other BBS systems as a sort of trophy, and a way to establish affiliations ("affilz") among other pirate boards: a way of rewarding good work with expanded access. As the division of labour sedimented and the warez scene grew, pirated goods became more sophisticated, and incorporated a greater variety of labour. Pirates began inserting their own introductory animations and musical compositions into cracked programs. These "cracktros" served to brand releases and show off the programming and compositional skills of pirates. Crews put together "releases" (archives with the file extension .ZIP) which compressed the file size and included an NFO file containing information about the crew who created it as well as multi-colored artwork (known as ANSI). In this they mimicked, often in an irreverent way, commercial releases. This is a kind of critique of the capitalist flow of digital commodities, a way to creatively articulate the vision for an alternatively organized Internet, where the fruits of the digital economy accrue based on merit and ability, rather than ability to pay.

In doing so, software pirates did not attempt to create an anti-capitalist space, but rather a differently organized capitalist space, with a more autonomous relationship to commodification and consumption. While members of the BBS underground dabbled in credit card fraud (often to purchase software and hardware to keep the scene running), pirated software was understood as explicitly noncommercial, and anyone caught selling pirated software was banned from the Scene (Goldman 2004). An early BBS scene magazine spells this out explicitly:

What's a pirate? COMPUTER PIRACY is copying and distribution of copyright software (warez). Pirates are hobbyists who enjoy collecting and playing with the latest programs. Most pirates enjoy collective warez, getting them running, and then generally archive them, or store them away. A PIRATE IS NOT A BOOTLEGGER. Bootleggers are to piracy what a chop-shop is to a home auto mechanic. Bootleggers are people who DEAL stolen merchandise for personal gain" ("So you want to be a pirate?" 1989).

Indeed, as pirates themselves have repeatedly avowed, pirates dutifully purchase goods. Thomas and Meyer (1990), sociologists who experimented with publishing their research in the format of a pirate 'zine textfile, argued, "software pirates [...] report spending considerably more money purchasing software than the average user. Many of these purchases are for trading, and there is a strong ethos in the pirate world that if one uses a program, one purchases it." Subsequent research indicates that pirates tend to purchase more media 
goods than those who do not pirate (Karaganis 2011). Software pirates also argued that their practices spread computer literacy among young people who were unable to purchase software, but would become good consumers later in life. The .NFO files in pirate releases, which served as a kind of manifesto or newsletter for release groups, often contained exhortations to support quality software releases: "IF YOU ENJOYED THIS PRODUCT, BUY IT! SOFTWARE AUTHORS DESERVE SUPPORT!!" (Smith 2004).

In this way, piracy does not reject commodification outright. Rather, pirates seek to manage the deluge of expensive software in an economically viable way, testing products and developing skills before deciding what to buy. This bears strong similarities to the strategy of autoreduction in 1970s Italy, during which workers resisted inflation and price increases by paying the old price. Cherki and Wieviorka $(2007,72)$ identify how these struggles had "stakes tied to consumption": working class neighborhoods organized, with unions, against rate hikes for utilities and services by refusing to pay the new rates. The battle to lower prices for commodities were taken up by the formal labour movement itself, as struggles extended beyond the workplace.

The class composition of pirate organizations led to specific political limitations. Only users of a certain ability - with sufficiently developed computer and networking skills-are able to participate in this autonomous strata of users. Competitive pressures among pirates mitigate some of the more egalitarian qualities of generating commons of software. Importantly, The Scene (and hacking generally) tends to be male-dominated, and even misogynist; it is also based in the wealthy nations of Europe and North America. This curtails the mass political potentials of these kinds of pirate organizations.

There are further limits. While this paper has aligned piracy with a number of Marxist critiques of capitalism, it is less clear that pirates share this critique. As Sergio Bologna (1972, 6 ) noted in his analysis of the German workers' movement, demands for self-management and the preservation of skill emerge from "a labour force inextricably linked to the technology of the labour process, with a strong sense of professional values and naturally inclined to place a high value on their function as "producers." This makes for a struggle that is difficult to generalize to the entire class of users, and tends towards hierarchical, vanguardist forms of organization focused on self-management of work. This description suits The Scene, which reproduces many of the liabilities of a labour aristocracy. Furthermore, because decommodification of intellectual property is tied to self-management of work, it tempers what may otherwise appear as egalitarian redistribution of the social product. This research suggests these tendencies were present in computer countercultures from their inception. Future research on the politics of computer-based countercultures, this essay suggests, should problematize the prioritization of skill within these cultures, especially when assessing the political potentials of such formations.

Ultimately, the struggles of early pirates cannot be understood as strictly in favor of, or against, capitalist social relations. While they struggled against elements of control and management in favor of individual autonomy, and even developed organized social and cultural practices to achieve these aims, they stopped short of a connecting the encroachment of a regulated and deskilled Internet to the deepening subsumption of online social relations to capitalism. Subsequent research will examine how this political terrain changes when piracy moves from beyond an elite framework limited to skilled users to a mass phenomenon, aided by software platforms (such as Napster).

\section{References}

Adorno, Theodor. 2001. Free Time in The Culture Industry: Selected Essays on Mass Culture, edited by J.M. Bernstein, 187-197. London: Routledge.

Aglietta, Michel. 2001. A Theory of Capitalist Regulation: The US experience. London, UK: Verso Classics.

Benkler, Yochai. 2006. The Wealth of Networks. New Haven, CT: Yale University Press.

Bologna, Sergio. 1972. Class Composition and the Theory of the Party at the Origin of the WorkersCouncil Movement. Telos 13: 4-27.

Boutang, Yann-Moulier. 2012. Cognitive Capitalism. London, UK: Polity. 
Boyle, James. 2003. The Second Enclosure Movement and the Construction of the Public Domain. Law and Contemporary Problems 66 (33): 33-52.

Braverman, Harry. 1998. Labour and Monopoly Capital: The degradation of work in the twentieth century. New York, NY. Monthly Review Press.

Brenner, Robert. 2006. The Economics of Global Turbulence. New York, NY: Verso.

Caffentzis, George. 2013. In Letters of Blood and Fire: Work, Machines, and the Crisis of Capitalism. Oakland, CA: PM Press.

Cherki, Eddy and Michel Wieviorka. 2007. Autoreduction Movements in Turin. In Autonomia: PostPolitical Politics, edited by Sylvere Lotringer and Christian Marazzi, 72-78. Los Angeles, CA: Semiotext(e).

Cleaver, Harry. 2000. Reading Capital Politically. London, UK: AK Press.

Coleman, Gabriella. 2009. Code is Speech: Liberalism, Legality, and the Ethics of Free Software. Cultural Anthropology 24 (3): 420-454.

"Cracking Tips (Part 1)." Pirate, accessed June 14, 2014. http://www.textfiles.com/magazines/PIRATE/pirate-3.

Craig, Paul. 2005. Software Piracy Exposed. Boston, MA: Syngress.

Dafermos, George and Johan Söderberg. 2009. The hacker movement as a continuation of labour struggle. Capital \& Class 97: 53-73.

Dalla Costa, Maria and Selma James. 1973. The Power of Women and the Subversion of the

Community, 3rd Edition. London, UK: Falling Wall Press.

Debord, Guy. 1995. Society of the Spectacle. Translated by Donald Nicholson-Smith. New York: Zone Books.

Décary-Hetu, David, Carlo Morselli, and Stéphane Leman-Langlois. 2012. Welcome to the Scene: A Study of Social Organization and Recognition among Warez Hackers. Journal of Research in Crime and Delinquency 49: 359-382.

Deleuze, Gilles. 1992. Postscript on the Societies of Control. October 59: 3-7.

Ford, Martin. 2015. Rise of the Robots: Technology and the Threat of a Jobless Future. New York, NY: Basic Books.

Foucault, Michel. 1977. Discipline and Punish: The Birth of the Prison. Translated by Alan Sheridan. New York, NY: Vintage Books.

Fuchs, Christian. 2012. Dallas Smythe Today-The Audience Commodity, the Digital Labour Debate, Marxist Political Economy and Critical Theory. Prolegomena to a Digital Labour Theory of Value. tripleC: Communication, Capitalism \& Critique 10 (2), 692-740. Accessed December 4, 2015. http://www.triple-c.at/index.php/tripleC/article/view/443.

Fuchs, Christian. 2014. Digital Labour and Karl Marx. New York: Routledge.

Fuchs, Christian and Marisol Sandoval. 2014. Digital Workers of the World Unite! A Framework for Critically Theorising and Analysing Digital Labour. tripleC: Communication, Capitalism \& Critique 12 (2). Accessed December 2, 2015. http://www.triple-c.at/index.php/tripleC/article/view/549/605.

Gill, R.C. and A. Pratt. 2008. In the social factory? Immaterial labour, precariousness and cultural work. Theory Culture \& Society 25 (7-8): 1-30.

Goldman, Eric. 2003. A Road to No Warez: The No Electronic Theft Act and Criminal Copyright Infringement. Oregon Law Review 82: 369-432.

Goldman, Eric. 2004. Warez Trading and Criminal Copyright Infringement. Journal of the Copyright Society of the U.S.A. 51: 395-435.

Haight, Bev. 1981. They Don't Want their Readers to Back Up "Protected" Disks!: Censorship in Computer Magazines. Hardcore Computing 1 (1).

Hall, Stuart. 2003. Marx's Notes on Method: A "reading" of the "1857 Introduction". Cultural Studies 17 (2): 113-149.

Hargadon, Michael A. 2001. Like City Lights, Receding: ANSi Artwork and the digital underground, 1985-2000. Master's thesis, Concordia University.

Harvey, David. 2005. A Brief History of Neoliberalism. Oxford, UK: Oxford University Press.

Howe, Jeff. 2005. The Shadow Internet. Wired 13 (01). Accessed June 14, 2014. http://www.wired.com/wired/archive/13.01/topsite.html.

Kelty, Chris. 2008. Two Bits: The Cultural Significance of Free Software. Durham, NC: Duke University Press.

Kline, Stephen, Nick Dyer-Witheford, and Greig de Peuter. 2003. Digital Play: The Interaction of Technology, Culture, and Marketing. Montreal, QC: McGill-Queen's University Press. 
Lin, Albert. 1995. Hacker/Pirate interaction in the computer underground. Unpublished paper. Accessed November 30, 2015. http://groups.csail.mit.edu/mac/classes/6.805/student-papers/fall95papers/lin-pirate.html.

Linebaugh, Peter and Marcus Rediker. 2005. The Many-Headed Hydra: Sailors, Slaves, Commoners, and the Hidden History of the Revolutionary. Atlantic. Boston, MA: Beacon Press.

Mandel, Ernest. 1999. Late Capitalism. London, UK: Verso Classics.

Manzerolle, Vincent. 2010. Mobilizing the audience commodity: Digital labour in a wireless world. Ephemera 10 (3-4), 455-469. Accessed December 4, 2015.

http://www.ephemerajournal.org/contribution/mobilizing-audience-commodity-digital-labourwireless-world.

Marx, Karl. 1911. A Contribution to the Critique of Political Economy. Translated by N.I. Stone. Chicago: Charles $\mathrm{H}$. Kerr and Co.

Marx, Karl. 1990. Capital Volume 1. Translated by Ben Fowkes. London: Penguin Books.

Marx, Karl. 1993. Grundrisse. Translated by Martin Nicolaus. Harmondworth: Penguin Books.

Moody, Kim. 1997. Workers in a Lean World: Unions in the International Economy. New York, NY: Verso.

Pfeiffer, Sabine. 2014. Digital Labour and the Use-value of Human Work: On the Importance of Labouring Capacity for Understanding Digital Capitalism. tripleC: Communication, Capitalism \& Critique 12 (2). Accessed December 1, 2015. http://www.triplec.at/index.php/tripleC/article/view/545/611.

Reunanen, Markku. 2014. How Those Crackers Became Us Demosceners. WiderScreen 1-2.

Rediker, Marcus. 2005. Villains of All Nations: Atlantic pirates in the Golden Age. Boston, MA: Beacon Press.

Smith, Andrew. 2004. A Guide to Internet Piracy. 2600: Hacker Quarterly 21 (2). Accessed June 14, 2014. https://opentrackers.org/i/2600 Guide to Internet_Piracy-TYDJ.txt.

Smith, Tony. 2000. Technology and Capital in the Age of Lean Production: A Marxian critique of the "New Economy". Albany, NY: State University of New York Press.

"So you want to be a pirate?" 1989. Pirate. Accessed June 14, 2014. http://www.textfiles.com/magazines/PIRATE/pirate-1.

Spangler, Todd. 2014. Pirated copy of "Walter Mitty" surfaces online with "Ellen DeGeneres" watermark. Variety. Accessed June 14, 2014. http://variety.com/2014/digital/news/walter-mitty-piratedellen-degeneres-1201044105/.

Stallman, Richard. 2009. Free Software, Free Society: Selected essays of Richard M. Stallman, Edited by Joshua Gay. CreateSpace.

Steiner, Christopher. 2012. Automate This: How Algorithms Took Over Our Markets, Our Jobs, and the World. New York, NY: Penguin.

Thomas, Jim and Gordon Meyer. 1990. Software Piracy: An alternative view. Computer Underground Digest 1 (1.03). Accessed June 14, 2014. http://www.textfiles.com/magazines/CUD/cud0103.txt.

Thompson, E.P. 1966. The Making of the English Working Class. New York, NY: Vintage.

Virno, Paolo. 1996. Notes on the "General Intellect". In Marxism beyond Marxism, edited by Saree Makdisi, Cesare Casarino and Rebecca E. Karl, 265-272. New York, London: Routledge.

Virno, Paolo. 2001. General intellect. In Lessico Postfordista, edited by Zanini and Fadini, translated by Arianna Bove. Milan: Feltrinelli. Accessed June 14, 2014. http://www.generationonline.org/p/fpvirno10.htm.

Wasiak, Patryk. 2012. "Illegal Guys": A History of Digital Subcultures in Europe during the 1980s. Zeithistorische Forschungen 9 (2).

Wood, Ellen Meiskins. 2002. The Origin of Capitalism: A Longer View. London, UK: Verso.

Who is stealing your future? Creative America. Accessed June 14, 2014. http://www.creativeamerica.org/media/uploaded/resources/13 1319503120 ContentTheftFactShe et.pdf.

\section{About the Author}

Gavin Mueller

Gavin Mueller holds a Ph.D. in Cultural Studies from George Mason University. He researches the cultural history of the Internet, online social movements, and emergent digital labour practices. $\mathrm{He}$ is a contributing editor to Jacobin Magazine and an editor at Viewpoint Magazine. 